Educational Research for Social Change (ERSC)

Volume 7 No. 2, September 2018

pp. 22-38

ersc.nmmu.ac.za

ISSN: 2221-4070

\title{
A critical look at a technologically sophisticated initiative to address the problem of unequal educational opportunities in South Africa ${ }^{1}$
}

Leentjie van Jaarsveld

North-West University

Leentjie.vanjaarsveld@nwu.ac.za

Johannes L. van der Walt

North-West University

Hannesv290@gmail.com

\section{Abstract}

A survey of the literature in connection with the current state of education in South Africa reveals a consensus that the system has remained unfair to a large section of the population, even now - two decades into the postapartheid dispensation. The education system has now developed two distinct tiers: one for the historically privileged and one for historically disadvantaged learners, the latter by far the larger of the two. In addition to measures taken by the Department of Basic Education to close the gap between these two tiers, some of the historically privileged schools have launched initiatives to help their less fortunate counterparts overcome the disparities and unfairness of the current system. This paper takes a critical look at one such initiative, a project that is technologically sophisticated and from which all historically disadvantaged schools may potentially benefit. Although the project has been well meant by its initiators, and although it already has benefited some 38 underprivileged schools since 2008, it is a stark illustration of the persistent disparities in the South African education system. The project nevertheless has transformative potential.

Keywords: critical pedagogy, education, teaching and learning, teaching-learning technology, South Africa

Copyright: (C) 2018 Leentjie van Jaarsveld and Johannes L. van der Walt

This is an open access article distributed under the terms of the Creative Commons Attribution Non-Commercial License, which permits unrestricted non-commercial use, distribution, and reproduction in any medium, provided the original author and source are credited.

Please reference as: Van Jaarsveld, L. \& Van der Walt, J.L. (2018). A Critical Look at a Technologically Sophisticated Initiative to Address the Problem of Unequal Educational Opportunities in South Africa. Educational Research for Social Change, 7(2), 22-38. http://dx.doi.org/10.17159/22214070/2018/v7i2a2

\section{Introduction}

\footnotetext{
1 Ethical clearance number: NWU-00027-15-A2
} 
There seems to be agreement that most (around 80\%, according to Van der Berg, 2008) of South Africa's schools could be regarded as dysfunctional and underachieving. Opinions differ about the causes of this situation. Observers such as Timaeus, Simelane, and Letsoalo (2013) contended that even after two decades of postapartheid education, and after large amounts of money and resources have been expended on the historically disadvantaged (historically black) schools, the education system is still struggling to overcome the backlogs brought about by apartheid. In saying this, they agreed with Moloi, Gravett, and Petersen (2009) who stated, a decade ago, that the external environment in which South African education institutions worked had become complex, uncertain, and challenging. In the opinion of Timaeus et al. (2013) and Moloi et al. (2009), the legacy of poverty and inequality was an ever present constraining force for schools located in disabling contexts (in terms of inadequate teaching and learning and physical, material, and financial resources). These schools were nevertheless expected to compete with the historically well-resourced schools.

\section{Background and Statement of the Problem}

In view of what has been stated above, the problem on which the research reported in this article centred was formulated as follows: "Could there be other solutions to the problem of the inequality of opportunity within the South African school system besides just waiting on the Department of Basic Education to take appropriate action?"

The following steps were taken to examine this problem: First, we scouted around for initiatives for addressing the problem from the private sector, the broad citizenry, the different communities involved, other schools (particularly more affluent ones), the public sector, and individuals. This exercise brought several such approaches to our attention, for instance, the Interactive-GIS-Tutor (IGIST) - a multimedia teaching tool (Fleischmann \& Van der Westhuizen, 2017), the Content and Language Integrated Learning (CLIL) approach to improve learning of languages and different subject matters (Mathole, 2016), and the Khanya Project, an initiative using technology to enhance teaching and learning in one of South Africa's most diverse provinces, the Western Cape (Mlitwa \& Koranteng, 2013), to name but a few. One of these initiatives struck us as exceptionally promising because it had, by the time of our investigation, already benefited around 25 less privileged (historically black) schools (at the time of writing, this number has grown to 38). We then examined the initiative critically to see whether it was an approach that we could support and urge other schools to follow. This article contains the findings, based on our critical examination of the initiative taken in this particular case. The remainder of this section sketches in greater detail the problem that South African schools have to deal with and which, as mentioned, has become the research problem around which this article centres.

Van der Berg, Taylor, Gustafsson, Spaull, and Armstrong (2011) lamented, some years ago, that the failure to provide decent education, especially to the historically disadvantaged, was one of the most spectacular failures of the previous 13 years. Other authors were of the opinion that apartheid could not be the root cause of the problem after two decades of democratic government. They tended to blame managerial shortcomings for the state of affairs in schools. According to Van der Berg (2008, p. 145), for instance, studies have shown "high variability in school performance ... even after controlling for socio-economic status (SES) and teacher inputs . . . that may be indicative of varying efficiency, hinting at managerial problems in many schools." Turnbull's explanation of the state of affairs in historically underprivileged schools also hinted at management problems:

Public schools are funded through the quintile system designed to redress the inequalities of distribution in education, but which is seen to be failing in part due to the fact that the 
criteria applied to identify a school's band have not been amended as the population distribution has changed, as acknowledged by the government. Further, the funding received by township schools only provides for the basic needs of the school, falling short of the funding provided for white-only schools during apartheid. Thus, the most deprived schools retain high class sizes and poor facilities. . . The introduction of partial or full exemptions from school fees and the introduction of no-fee schools in the poorest areas have not changed the disadvantage experienced by township principals, as there has been no significant additional funding to replace the school fees needed. The inequality in educational provision in public schools was maintained, resulting in a two-tier public education system rather than a single system of public education providing equality of opportunities. (2014, p. 103)

Bush and Glover (2014) concurred by pointing out that schools in townships, rural areas, and informal settlements continue to experience a range of problems including inadequate infrastructure, under trained and demotivated educators, low expectations, and poor post-school employment prospects.

The second round of the South African Consortium on Monitoring Education Quality (SACMEQ II) evaluation reported that in 2001, after seven years of postapartheid education, there still was exceedingly high inequality between rich and poor schools and, also, between schools in the cities and those in far-flung rural areas (as cited in Van der Berg, 2008). The greatest disparity, according to SACMEQ II, was in terms of the two tiers mentioned by Van der Berg (2008): between rich schools (mainly historically white and Indian-around $10 \%$ of all schools) and other schools (mainly historically black schools). The superior performance of the former may have been due to both greater private resources and greater school efficiency in converting outputs into performance. According to Van der Berg (2008), SACMEQ II (2005) data demonstrated that socioeconomic differentials were still playing a major role in 2000 in educational outcomes, particularly at primary school level.

Based on the SACMEQ III (2007) results, Spaull (2013) concluded that the situation had not improved significantly by 2007. According to him (Spaull, 2013), the weight of evidence supported the conclusion that there was an ongoing crisis in South African education - that the current system was failing the majority of South Africa's youth. A variety of independently conducted assessments of pupil achievement showed that, again with the exception of a wealthy minority, most South African pupils could not read, write, or compute at grade-appropriate levels, with large proportions being functionally illiterate and innumerate. As it stands, Spaull (2013, p. 3) concluded, "the South African education system is grossly inefficient, severely underperforming and egregiously unfair." This situation had not improved by 2015 . Christie recently contended that

more than two decades later, South Africa remains profoundly unequal, as is evident in all dimensions of education provision. Despite some shifts in apartheid race/class configuration, the burden of poverty and poor education is still shouldered disproportionately by black people... . The practices of everyday life (including education) follow the rhythms of a fundamentally unequal neoliberal political economy. . . . the reasons for the difficulties in achieving social justice after conflict lie in the entanglement of different social practices and the slippages and contradictions that inevitably occur between them. (2016, p. 435)

At the other end of the spectrum, around three per cent of children attend independent schools (Republic of South Africa, 2010), and these typically have considerably more favourable staff-pupil ratios and better facilities than public schools (Timaeus et al., 2013). 
A SACMEQ II (2005) finding relevant to the problem discussed in this paper was the fact that equipment, measured on a scale of 0-11 (a count of the presence in the school of a first aid kit, a fax machine, typewriter, duplicator, radio, tape recorder, overhead projector, TV, VCR, photocopier, and computer) played a positive role in the learners' level of achievement; and particularly for mathematics, school buildings (on a scale of 0-6: a count of the presence of a school library, school hall, teacher room, office for the principal, storeroom, and cafeteria) also impacted on scores. Wellequipped schools in large cities performed much better than other less well-equipped schools. As mentioned, the superior performance of richer schools may have been due to greater private resources and greater school efficiency in converting the inputs into performance (Van der Berg, 2008). On the other hand, as Van der Berg (2008) observed, the availability of more and better resources did not necessarily or without qualification improve school performance. The message from SACMEQ II appeared to be not that resources did not matter but, rather, that resources mattered only conditionally.

Timaeus et al. (2013) recently observed that many of the historically underprivileged schools still operate in inadequate buildings and that a significant minority of rural schools still lack electricity connections, phone lines, and running water. Many older African teachers received a very poor training in apartheid-era colleges and it has proved difficult to establish professional development programmes that could win the support of the entire teaching profession and effectively address the inadequate skills of some teachers. It is the large divergence in the ability of schools to convert resources into outcomes that is the issue requiring policy attention.

Such inquiry is required because, as Spaull (2013) discovered, the vast majority of South African pupils are significantly below where they should be in terms of the curriculum. A major problem in this regard is the lack of subject content knowledge among their teachers in poor schools, particularly in rural areas. This finding has been substantiated by the TIMSS (Trends in International Mathematics and Science Study), showing that Grade 9 pupils from Quintiles 1 and 2 schools were performing at least three years behind Quintile 5, Grade 9 pupils (Spaull, 2013, p. 5). Spaull's computations showed that

for disadvantaged pupils, the gaps between what they should know and what they do know grow over time. This means that as time goes on, children fall further and further behind the curriculum leading to a situation where remediation is almost impossible in high school since these learning gaps have been left unaddressed for too long. The analysis of pupils in the Eastern Cape showed that while pupils are already 1,8 years behind the benchmark by Grade Three, this grows to 2,8 years behind the benchmark by Grade Nine, making effective remediation at this higher grade improbable. (Spaull, 2013, p. 6)

Technology is another aspect of the problem that has to be considered. The use of technology in learning environments is today regarded as something natural for the current generation of pupils used to exposure to electronic devices. For such pupils, technology as learning tool and support is not merely convenient but also, possibly, an appropriate modality for addressing current trends in learning styles and preferences. Letwinsky $(2017$, p. 57) correctly argued that this generation of pupils interacts with the world in a way that is more immediate, more technological, and more social than before. In order for technology integration to be effective, it should be integrated in teaching and learning processes, thereby allowing students to be able to select technology resources to help them obtain information in a timely manner, analyse and synthesise information, and present it professionally (Harris, 2016, p. 27). According to Leahy et al. (2016), smart learning environments and smart classrooms use technology to tailor learning to the needs of individual students, providing immediate feedback and support. The term smart in this context suggests innovative and transformative changes driven by new technologies. It brings up notions of data-driven decisions and technology-enabled data sharing, plus communications and collaboration, all leading to continuous improvement. The term 
smart school, according these authors, denotes "a learning institution that has been systematically reinvented in terms of teaching/learning practices and school management in order to prepare children for the Information Age" (Liu, Huang, \& Wosinski, 2017, p. 224). In terms of the outline above, the disadvantaged schools in South Africa can by no means be referred to as smart schools; in fact, most of them lack some of the most rudimentary technology such as proper black boards, posters, and overhead projectors.

The above outline of the wide array of problems that historically disadvantaged schools in South Africa have to contend with underscores that it has become necessary to examine projects that might lead to an amelioration of the situation. The remainder of this paper is devoted to a description and critical evaluation of such a project originally undertaken by a number of schools in relatively close proximity to one another: a Quintile 5 school (formerly privileged white school) and several Quintiles 1 and 2 schools (formerly underprivileged black schools). The next two sections contain brief discussion of the approach and method that we have followed in assessing the solution offered by these schools. The section thereafter is devoted to an outline of the project and its outcomes. The article concludes with a critical evaluation of the project, its viability, strengths, and shortcomings.

\section{Critical Pedagogy as Theoretical Lens}

Our stance is interpretive-hermeneutic (Lusenga, 2010) in order to understand the dynamics of the current pedagogical inequality in South Africa as part of the complex world in which people live with their own intentions, values, and beliefs. We are also critical of, for instance, the (abuse of) power relations in our society. According to a critical pedagogical orientation, educationists should be radically engaged with the current political and economic hegemony (Simons, 2006). They should engage with social and educational justice issues, the difficulties of learners in gaining access to literacy, education, educational opportunities, with conflict, sustainable development, the imperative to meet students' needs, inequality and inequity, emancipation of suppressed groups, sustainable and empowering learning, historical legacies that hold education captive, cultural and other complexities, and community engagement. In the end, our critical input should contribute to social, particularly school change, and to improved learner performance.

We regard social and pedagogical justice as the guiding light in our critical assessment of the project described below; our awareness of norms and principles leads us to see human beings as moral beings (Strauss, 2009). As moral beings, humans can be expected to behave justly and fairly towards otherslearners, in this case-(Strauss, 2009). To do so, forms part of the social contract between governments and their citizenries and of educational managers (from the Minister of Basic Education to the teacher in the classroom) with parents, learners, and the communities. This orientation has many ramifications: it refers to the rights that every human should enjoy, it pertains to ethics (doing to others as one would have them do to you), the well-being of every individual and of society in general, the improvement of the quality of life of all concerned, the responsible use of power, the role of the state in all of these actions, to mention only some (cf. Grayling, 2010, p. 217).

While we commend the fact that, as will be described below, a historically privileged school entered into a joint project with previously disadvantaged schools for the purpose of assisting the latter to overcome the injustices of the past and the persistent backlogs that they have been struggling with, we will, in our assessment of the project, be critical of the approach of the previously (and currently, still) privileged school. 


\section{Method of Investigation}

The investigation was embedded in an interpretative qualitative design. The aim was to discover and understand the phenomenon in question, how people were involved, and what their opinion was about the phenomenon (Merriam, 2002). We visited the five schools $(N=5)$ discussed below. We first attended the broadcasting of the lessons at the receiving schools and observed the behaviour of the teachers and learners during these broadcasts. After the broadcasts, we interviewed the teachers ( $N$ $=8)$ and then the principals $(N=4)$ of these schools.

The interviews with the principals were conducted in their offices while the interviews with the teachers were conducted in their classrooms where the interactive whiteboards had been installed. The male teachers insisted on being interviewed in the classrooms where the whiteboards were installed, whereas the female teacher preferred to be interviewed in a classroom without a whiteboard. This difference could be attributed to the fact that the male participants had taken ownership of the classrooms where the whiteboards were installed whereas the female participant only used the classroom from time to time.

Face-to-face, semi-structured interviews were conducted with the participants in the secondary schools. Open-ended questions were asked to elicit the views and opinions of the participants (Creswell, 2014). The interviews lasted an hour each. The questions put to the principals and teachers were aimed at determining the value of the project with regard to the teaching and learning process. The impact of technology as a factor in the improvement of results of mathematics and physical sciences was also discussed.

The interviews were afterwards transcribed and scrutinised for inconsistency. This was followed by an inductive data analysis process during which the data were organised, encoded, and categorised in themes and subthemes that emerged from the analysis. Merriam (2009, pp. 175-176) correctly argued that data analysis consolidates, reduces, and interprets what the participants said and what the researcher saw and read, thereby giving a meaningful process to the data.

We also walked around the various school premises and observed the behaviour of all role players. We specifically observed the behaviour and attitude of the learners in classes where interactive whiteboards were installed, and compared them with those without the interactive whiteboards.

Our critical pedagogical approach was complemented by a transformative stance, as evidenced in the critical evaluation of the project (see below). By transformative, we mean that, despite the shortcomings of the project, we see possibilities for change and improvement in the project that could be advantageous to the social welfare of the participants (de Lange, Moletsane, \& Mitchell, 2015, pp. 152, 169, 172; Ungerer, 2014, p. 4).

Our approach to the research had certain limitations. Given that we as the researchers were the major data collection instruments, our closeness to the topic and our own value systems could have played a distortive role in creating limitations in the research. Our critical pedagogical and transformative approach to the situation in both the broadcasting and the receiving schools could have led us to be more keenly aware of those factors in the schools and in the project that were in alignment with our original research orientation. The fact that as researchers we were racially and culturally different from most of the teachers and learners at, particularly, the receiving schools might also have tainted our observations. 


\section{The Project}

\section{Its purpose}

According to the management of the source or broadcasting school, the initial purpose of the project was to support learners who wished to attain university admission. Gradually, however, the net was cast wider in that the project began working towards improving the general quality of teaching in mathematics and science through equipping the teachers in the receiving schools. The initial aim was broken down into several goals:

- To assist rural and underperforming schools in teaching mathematics and science.

- To offer an online service to all schools for live tutoring by experienced mathematics and science teachers.

- To improve Grade 12 results.

- To train mathematics and science teachers to become specialist teachers.

- To share online mathematics and science resources with schools connected to the source school's online learning network.

- To manage and monitor all LES ${ }^{\circledR}$ projects connected to the source school's online learning network. The LES ${ }^{\circledR}$ system remotely connects students from rural and underperforming schools, training centres, and boardrooms by means of laptops, desktops, tablets (only Windows OS), interactive whiteboards, desktop sharing, and audio/video streaming.

\section{The source school}

While all the schools concerned (one historically and still materially privileged and, initially, 25 historically and currently underprivileged) were aware of the need to utilise teaching and learning technology to close the digital gap between these two categories of schools in a rural area in Mpumalanga Province in the eastern part of South Africa (cf. Moloi, Gravett, \& Petersen, 2009), only the source school was able to afford the installation of sophisticated teaching aids at all the schools. The source school began the project in 2008 because its management realised that the school and its teachers possessed expertise in mathematics and science that they could-and should, in their opinion-share with less functional schools in their vicinity. The principal was a white man and had 35 years' experience. The teachers who were interviewed were white women with at least 15 years' teaching experience each. English and Afrikaans were the languages of instruction in the school. The broadcasts to the receiving schools were all in English.

\section{Target schools}

Only three receiving schools joined the project initially (2008). This number has since grown steadily; 25 receiving schools were involved in the project in 2015, and 38 by the end of 2016. The project was launched by a number of schools in relatively close proximity to one another (initially within a 50kilometre radius), that is, not close enough for them to merge and become a single school, but sufficiently removed from one another to utilise relevant teaching technology.

In 2015, the source school began developing technology that would enable any other school in South Africa to join the project. Any school could from then on connect with the source school by means of video conferencing technology, a cloud server, and internet connections. By the end of 2016, around 3,600 Grade 12 learners had been involved in the project. Approximately 24,000 learners in lower grades are currently benefiting from the technology that has been installed in the schools. More 
schools will be encouraged to join the project in 2017-8. All the principals of the target schools were black men and had at least 15 years' teaching experience each. The teachers interviewed were black men and women with at least 15 years' teaching experience each. The language of instruction in the target schools was English throughout.

\section{Learning content}

Between 2008 and 2015, mathematics and science lessons were transmitted to help the Grade 12 learners in the receiving schools to achieve better pass rates, thereby enabling them to go to universities for further studies in these disciplines. In the course of 2015, the learning package was expanded to include all the themes for mathematics and science prescribed for Grades 8 to 12 learners by the Curriculum Assessment Policy Statements (CAPS). At present, the package contains daily lessons, video presentations that have been prerecorded, as well as questions regarding themes, together with the necessary memoranda.

Lessons are broadcast on Monday and Tuesday mornings when the other learners at the receiving schools are involved in the school opening in the school hall. Lessons last an hour each. During the October recess, special classes are offered on six consecutive days. These broadcasts are mainly devoted to revision and summaries that learners might need for exam preparation.

\section{Technology involved}

Learners at the receiving schools are connected to the broadcasts in training centres and boardrooms through the abovementioned LES ${ }^{\circledR}$ system. The broadcasts are live and interactive. After examining all its options, for example E-beam, Parrot, Edu-board and Promethean, the source school decided on the SMART technology to broadcast the standard lessons normally given in the school. The term SMART is a trade name for an e-learning project, a configuration of technical teaching aids that allows sharing interactive educational technology with other schools. Since 2015, the source school has been using SMART Board interactive whiteboards, together with SMART Notebook and SMART Ideas conceptmapping software, and the SMART Sync classroom management system.

\section{Equipment for teachers}

The digital gap is being bridged by means of the infrastructure provided by the source school. The teachers of the target schools are being trained so that they can teach their learners after the broadcasts. Prepared lessons are provided to the target schools' teachers so that they can master the content beforehand. The target schools' learners get the opportunity to work together with expert teachers and learners of the source school (Kalp \& Maritz, 2009).

\section{Financing}

Due to the fact that the source school disposes of relatively large resources in the form of departmental, parental, business, and community funding, it has succeeded in creating a teaching aid infrastructure that is not commonly found even among historically privileged schools in South Africa. The project is funded by means of a public-private sector participation process in terms of which the Mpumalanga Department of Education (through the Mpumalanga Education Development Trust) matches - on a rand for rand basis - contributions from the private sector (Kalp \& Maritz, 2009). 


\section{Management of the project}

Management plays a key role in the success of the project and consists of a steering committee, project manager, installation, monitoring, maintenance, and career guidance committees.

\section{Results of the project}

This network of cooperation, transfer of knowledge, and exchange and support has resulted in improvement in the results of the receiving schools during the past few years. Table 1 contains the pass rates for mathematics and science of four of the receiving schools for which statistics are readily available.

Table 1: Grade 12 pass rate-Science

\begin{tabular}{lllllll}
\hline School & 2010 & 2011 & 2012 & 2013 & 2014 & 2015 \\
\hline Source school & $\begin{array}{l}\text { Not } \\
\text { available }\end{array}$ & $100 \%$ & $100 \%$ & $100 \%$ & $100 \%$ & $100 \%$ \\
\hline Receiving school A & $24 \%$ & $67 \%$ & $84 \%$ & $95 \%$ & $33.3 \%$ & $75 \%$ \\
\hline Receiving school B & $19 \%$ & $83 \%$ & $65 \%$ & $40 \%$ & $55 \%$ & $40 \%$ \\
\hline Receiving school C & $\begin{array}{l}\text { Joined in } \\
2011\end{array}$ & $80 \%$ & $71 \%$ & $93 \%$ & $85 \%$ & $100 \%$ \\
\hline Receiving school D & $34 \%$ & $59 \%$ & $58 \%$ & $31.3 \%$ & $33.3 \%$ & $53 \%$ \\
\hline
\end{tabular}

Table 2: Grade 12 pass rate-Mathematics

\begin{tabular}{lllllll}
\hline School & 2010 & 2011 & 2012 & 2013 & 2014 & 2015 \\
\hline Source school & $\begin{array}{l}\text { Not } \\
\text { available }\end{array}$ & $100 \%$ & $100 \%$ & $96.7 \%$ & $100 \%$ & $97.6 \%$ \\
\hline A & $19 \%$ & $53 \%$ & $63 \%$ & $100 \%$ & $83 \%$ & $88 \%$ \\
\hline B & $30 \%$ & $66 \%$ & $49 \%$ & $46 \%$ & $47 \%$ & $37 \%$ \\
\hline C & Joined in & $93 \%$ & $61 \%$ & $93 \%$ & $100 \%$ & $89 \%$ \\
\hline D & 2011 & $72 \%$ & $79 \%$ & $27.3 \%$ & $48 \%$ & $51.8 \%$ \\
\hline
\end{tabular}

School B temporarily withdrew from the project in 2015 when a new principal was appointed. The school has recently rejoined the project.

A comparison of the results of the receiving schools (Table 1) to those of the source school illuminates the discrepancies still existing in South Africa between the two tiers of schools to which reference was made above (see Table 3). 
Table 3: Grade 12 numbers of learners and numbers of distinctions (and 2015 pass percentages)

\begin{tabular}{|c|c|c|c|c|c|c|c|c|c|c|c|c|}
\hline School & 2010 & & 011 & & 2012 & & 2013 & & 2014 & & $2015^{*}$ & \\
\hline & 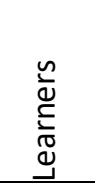 & 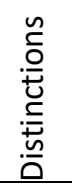 & 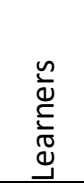 & 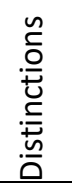 & 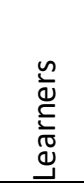 & 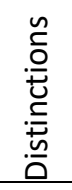 & 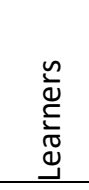 & 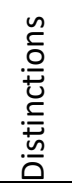 & 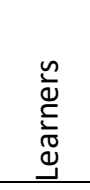 & 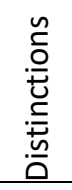 & 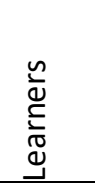 & 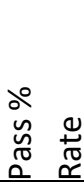 \\
\hline $\begin{array}{l}\text { Source } \\
\text { school }\end{array}$ & $\mathrm{n} / \mathrm{a}$ & $\mathrm{n} / \mathrm{a}$ & $\mathrm{n} / \mathrm{a}$ & $\mathrm{n} / \mathrm{a}$ & 126 & 129 & 168 & 175 & 161 & 125 & 170 & 99.4 \\
\hline $\begin{array}{l}\text { Receiving } \\
\text { school A }\end{array}$ & 52 & 0 & 62 & 1 & 93 & 1 & 99 & 14 & 153 & 4 & 144 & 91.7 \\
\hline $\begin{array}{l}\text { Receiving } \\
\text { school B }\end{array}$ & 54 & 3 & 51 & 4 & 55 & 4 & 67 & 3 & 67 & 12 & 194 & 41.2 \\
\hline $\begin{array}{l}\text { Receiving } \\
\text { school C }\end{array}$ & 23 & 14 & 24 & 17 & 17 & 6 & 21 & 20 & 20 & 6 & 23 & 78.3 \\
\hline $\begin{array}{l}\text { Receiving } \\
\text { school D }\end{array}$ & 24 & 4 & 39 & 1 & 30 & 4 & 24 & 0 & 40 & 10 & 52 & 65.4 \\
\hline
\end{tabular}

* The 2015 column contains the number of learners who wrote the Grade 12 examination and the percentage of passes. The number of distinctions scored at the different schools is not readily available for that year.

Race, as such, does not necessarily play a role in this discrepancy. Although the source school was a whites-only school during apartheid (i.e., before 1994), it has, since that date, been open to learners of all races. The fact that the school could maintain its momentum as far as its results in the Grade 12 final examinations are concerned, points to the fact that the school has acquired funds to employ a number of teachers in addition to those provided by the Department of Basic Education, thereby overcoming the problem of minimum funding of Quintile 5 schools by the Department. The management of the school has followed a number of strategies to not only ensure that the school keeps on performing as well as reflected in Table 2, but is also able to finance the state-of-the-art technology necessary for broadcasting its lessons and other training material to other schools whose performance still leaves much to be desired (Table 1).

\section{Results of interviews with parties involved in the project}

A visit to four of the receiving schools in 2015 revealed that some of those schools were not as effective as had been hoped when they had joined the project. Two teachers with whom interviews were conducted attributed this to weak management and difficulties with maintenance of the technical infrastructure. Observation of teachers' and learners' body language at one of these four receiving schools revealed that the role players were struggling with conflicting emotions as a result of their school's participation in the project. The same learners attended classes in the wing that received the broadcasts in mathematics and science, as well as in the wing that did not receive any broadcasts for other subjects. The teachers' and learners' body language in the former wing showed that they were industriously involved in teaching and learning, motivated for the work, and completely absorbed in what they were doing. In the latter wing, the teachers and the very same learners displayed a lackadaisical attitude; they arrived late for their lessons, they did not attend to the work, and generally seemed to laze around. They all seemed to respond to the difference in ambience in the two wings. This difference in mood between the wings could be ascribed to a number of conditions, of which the white board presentations or the lack thereof seemed to be the most prominent; the broadcasts occurred according to a fixed schedule and demanded punctuality from both teachers and learners. 
One teacher remarked as follows regarding the general mood in the school:

Now, if learners come to school and only teachers in certain subjects seriously teach, the whole mood of the school is affected because a learner can come and have two classes per day. What happens to the other hours? It kills the mood for the learners so that's what I'm saying. Sometimes a subject can fail because of the whole mood, the general mood of the school.

This concern about the mood in the school also found expression in criticism of the principal:

There are no priorities and sometimes it's just, he just reacts to situations and sometimes he cannot approach the proper people when there is a problem like right now if there is a class [in the wing without broadcasts] that is not attended when we meet again we are going to be told that teachers in certain grades, like so-and-so, you are not attending classes, and the culprit is not approached.

Another teacher remarked as follows about the school principal:

They've [i.e., the principal and his management team] made a mistake; when they are not doing their job properly people cannot really tell each other face-to-face. They try to go around and try maybe to include a group and try to say this as a group you are not doing this, but they know in the group who is not doing what. I see the response to disturbances in the school may be not up to scratch, you see. . . The school can be ... you see that learners decide learning but the rest of the school there, the people are not going to class and the management is there and not taking action.

Yet another teacher remarked:

How are we going to develop this school because we see that there is a problem? Say now there is a lot of noise so if other teachers are not in classes [in the wing without broadcasts] then what, what, what, you see? Just to manage the school by clarifying what are your aims and objectives of the school. What are the vision and the mission of the school? Are you fulfilling those vision and mission of the school? [The] purpose of the school is the teaching and learning.

A clearer picture of how the project works and is experienced at the receiving schools can be derived from the following qualitative data gleaned from the interviews:

I can say it is now easier to teach, because the resources are there even when you are researching for a topic you have a computer in front of you which is connected to the internet and you can have your... we can even have [the] same the notes from the source school and you can present the same lesson if you want or you can use it as the guideline and you can modify it to suit your particular needs. So it's much easier now to plan for a lesson to present it. It takes less time to prepare, and presentation is much easier. We can even use the simulations to interact with the learners so that they can see exactly how the concept can be demonstrated on the board easily, so I see it as teaching becomes much easier, more interesting, less painful.

Although, as remarked above, there has been a general trend of improvement in science and mathematics in the receiving schools, it is clear that not all schools showed such improvement. The 
qualitative data, in the form of transcribed interviews, cast light on this problem at the receiving schools:

It is very difficult really to quantify it [i.e., the gains provided by the project] in terms of the results that come out of the school at the end of each year. But if you look at it generally, the progress that this school has made since the progress came in, in terms of the resultsbut there are years that we have gone down and, because results are not about one thing - but generally you can see, I deal with the learners, the attitude you can see changes the moment they reach a stage where they have to come to my centre and we, they learn from there. So their attitudes change and generally the results of the school have improved from the time-because when the school joined the project in 2011 the previous year I think science had 21 or so percent, around 20 percent pass rate, but we have not been there after that. We, the trend, there is not a clear trend, but we have not gone that low again, which means it has an impact associated with the project.

They have to compare themselves with what other learners are doing from other schools. The level of participation even during the lessons, even results at the end. ... We compare results from other schools. There's School $X$ in the location. Another one $30 \mathrm{~km}$ away School $Y$, even the source school and we [School Z], we compare results. That brings out that spirit of competition in them.

The following transcriptions reveal how teachers and principals responded to the actual mode and content of the intervention.

You know in this programme we are using technology, ICT, computers, internet, and you know in this century, the 21st century you can't run away from that. There are a lot of benefits. It aids, it helps in the way you deliver your lessons. It enriches the way you deliver your lessons and the understanding from learners. They also understand better when you are using software programmes and the internet.

This project they, every week, they get a lesson that is transmitted by a teacher at the source school so they get another angle on the same subject. I'm also teaching them here, but they also have that opportunity to hear another side of the story from a different educator so it helps them in their understanding. And also the availability of the resources, it helps them in their research-internet and all the programmes that are in the system.

Usually during the holiday classes, there's, we usually go to the source school for holiday tuition and there they meet learners from other schools. They mingle, they share ideas, so it also enriches their experience as well and basically even during the transmissions they get to interact with other schools from different parts of the, of the district.

ICT it is giving them that edge to work even harder...

So we can conclude that now they are more serious because even the pass rate of the school has changed in science, especially and maths.

The qualitative data also show that there were management issues at one of the schools:

Yes, a lot, a lot [of management problems] because even me, maybe there's something that I was doing different. Now by seeing other person doing in other way, now I'm learning a lot because I can get many more thoughts. Now, oh, this one I can do this way. 
I can do this one in this way, I didn't know about that. There is a simple way to do other things. Maybe I was sticking in that difficulty.

There are no priorities and sometimes it's just, he [the principal] just reacts to situations and sometimes he cannot approach the proper people when there is a problem like, right now, if there is a class that is not attended when we meet again we are going to be told that teachers in certain grades, like so-and-so, you are not attending classes, and the culprit is not approached.

In one year to cover all the gaps, it becomes too much. They are now excited, they want to learn but it's a bit late. They can push to a certain level and sometimes some of them respond differently when they so much push-they get frustrated. They give up, they start other things to just disrupt, to make sure that you don't teach that, they spend that year like that and they don't, they don't, because what I'm saying is as a school if you look at the difference, if you go to the source school right now, it's quiet, everyone is teaching, everyone is in class, but here you can have some in class, some outside and if you, even from here you can hear that they, there are classes that are not attended there and those learners will eventually get to Grade 12 and we want them to pass when they get to Grade 12.

One of the teachers viewed proper management as follows:

For me it means that everyone there works towards a certain set of goals. They [source school management] are result oriented and nothing stops them from achieving what they set out to achieve. When they sit to discuss they are not discussing personal matters. They are discussing what can be done to influence the improvement of learners so I see that as a business mind because you have your clients, the learners who come in and you give them the service they need and they are satisfied with what they get in the school-unlike this side where probably learners come to our school and they don't get exactly what they set out to get. They, we frustrate them as a school we ... when they spend maybe some hours without being taught they don't achieve the results they set out to achieve.

You know when principals are managers how we are going to be, be, be ... they, they have to identify us and look at us in terms of how strong are we, where our weaknesses and then they try to manage our weaknesses professionally. So if a principal knows his team, he's going to know what to do when something, something ... to support, to make sure that learners are always attended to. So it's all about what strategies a principal is going to have to make sure that his school runs smoothly, because being a principal is a managing post and they have to have the skills to manage us.

\section{Critical Evaluation}

While all educators and educationists should harbour a deep appreciation for the initiative taken by a previously and currently privileged school to enter into a cooperative partnership with a relatively large number of historically and currently underprivileged schools in its vicinity, our critical-pedagogical orientation drives us to be critical as well as transformative about some aspects of the project. We will argue that the fact that the performance of most of the learners in the historically deprived schools participating in this project has improved to some extent, as illustrated in Table 1, should not blind us to the inherent shortcomings of projects such as these.

The fact that only one historically and currently materially privileged school is in a position to afford and launch a project such as this attests to the inherent inequality of opportunity still prevalent in the 
South African educational system. The ratio of one privileged school to 38 less privileged schools is testimony to the persistent inequality inherent in the system. What is shown by this is that privileged schools in South Africa are in a more favourable position to benefit from the socioeconomic differentials still existing in the country, that such schools are in a better position to attract funds from interested parties than their less developed counterparts in deep rural areas, that they have access to greater private resources (more affluent parents, businesses, and surrounding communities), and that they are able to operate efficiently in the current neoliberal economy of South Africa. All of this leads to the persistent inequality of pedagogical opportunities for learners in the two distinguishable tiers of the education system - something that is socially discriminatory and unfair to the less privileged. This finding once again points to the need for a system-wide change in South African education. The findings show that the training of school managers, particularly as leaders of historically disadvantaged schools participating in relatively technically sophisticated projects such as the one described above, should receive the greatest priority.

The one-directionality of the project, namely that broadcasts are made from a privileged school to a number of less privileged schools, attests to the built-in lack of opportunities for historically disadvantaged schools in the education system, as well as in the project. Reception of the broadcasts underscores for the underprivileged schools that they still do not possess the income, the financial means, or the technological infrastructure and expertise to do this work, and that they are dependent on a more affluent school for improving their achievements in selected school subjects.

Furthermore, South African learners are expected to offer at least six subjects for their final school examinations at the end of Grade 12 . This project assists them with only two, mathematics and science, which says something of the status of the other subjects, such as the so-called social or human science subjects in the minds of the project developers and leaders. Learners' underachievement in the remaining four subjects only serves to emphasise in the minds of the principals, teachers, learners, and parents at the receiving schools that they and their schools are still lagging behind the source school, which possesses the teachers and expertise to assist learners to do well in all the school subjects on offer.

It struck us that none of the teachers that we interviewed at the receiving schools ever referred pertinently to the SMART project, and how it had affected them or their schools. The typical responses, quoted above, seem to indicate that the SMART project had not essentially changed much in these schools. Confusion, a lack of resources and of effective management, of application to teaching and learning, weak discipline, and a lack of purpose still prevailed. The SMART project was obviously not seen as a solution to all the problems that these schools were experiencing-and we agree that it should not and cannot be seen as the final solution. It does assist the schools, teachers, and learners to improve their achievements in mathematics and science, but is not a final solution to all the complex difficulties that these schools have to contend with. The symptomatic treatment that the SMART project offers must be replaced by a system-wide whole-school solution as soon as possible.

The project has other downsides as well. As long as a project such as this is maintained, it emphasises to the principals, teachers, learners, parents, and communities of the receiving schools that they are still underprivileged in the "new" South Africa, that formerly white schools remain more privileged, and that white teachers still "know better" than black teachers, that the teachers in the historically privileged schools are still being better trained, that historically white schools are still better equipped in terms of technological infrastructure, that the principals in the receiving schools are compelled to accept handouts from richer schools, that the digital divide remains largely intact, and that the receiving schools still find themselves in the underprivileged tier in the education system. While the findings of this research seem to point to the urgency of addressing the problem, an immediate 
addressing of the problem seems to be unlikely given the current political and economic conditions in South Africa.

A word has also to be said about difficulties in the maintenance of the technology involved in the SMART project. Several of the receiving schools do not have electricity or running drinking water. Such circumstances pose challenging problems to the source as well as the receiving schools. Many of the schools can only be reached by means of road transport over badly maintained dirt roads. Since basic technological infrastructure, such as whiteboards and television screens, is absent in the receiving schools, these have to be transported, installed, and maintained at relatively high cost.

As mentioned, the critical-pedagogical paradigm that we have chosen for this study allows us to also take a transformative stance with respect to the research findings and the critical evaluation of the findings offered above. In terms of this stance, we find the cooperation between schools commendable and would like to see more schools participate in projects such as these, and preferably on a more even footing as equal partners and not as affluent schools reaching out to large numbers of less fortunate receiving schools. The lack of a more participatory and equitable partnership approach will have a detrimental effect on the long-term sustainability of the project because such an approach might prolong the inequality between the more affluent and the financially less fortunate schools. We are also convinced that projects of this nature should be built on a stronger recognition of the complexity of the different school contexts as well as of the challenges embodied by these contexts. Of particular importance is the cultural competencies of all involved, including those of the researchers (who appeared on the scene after the fact and from outside, as it were). As the project now stands, the broadcasting school is a historically advantaged school that has, in the past two decades, opened its doors to black learners. These learners can afford to attend this school because they come from financially affluent homes. In contrast, the receiving schools as well their learners are still caught up in the lower tier of the South African education system, that is, they have remained financially disadvantaged and have not had the opportunities allowed to learners from more advantaged social groups. Whereas the broadcasting school has, during the past two decades, changed from an all-white advantaged school to a racially and culturally diverse school, the receiving schools have essentially not undergone any changes as far as racial and cultural composition is concerned. The researchers who examined the project in both the broadcasting and the receiving schools were both white and Afrikaans speaking (one man and one woman). Taken together, this situation offers a complexity that offers many challenges for the further development of the project as well as for research on it.

\section{Conclusion}

Projects such as the SMART project described in this paper are often deceptive in that while they appear to be laudable if taken at face value, they often conceal negatives about the living and working conditions of the people involved. Taken at face value, the SMART project is commendable in the sense that it is the result of a sophisticated technological initiative undertaken by the principal and staff of a historically privileged school, and from which the teachers and learners of several historically underprivileged schools benefit. However, the SMART project should be viewed from the perspective of the receiving schools as well. It conceals a deep irony: while the SMART project might lead to some benefits for receiving schools, it simultaneously underscores that, by far, most of the schools in South Africa are still underprivileged, and the majority of learners in South Africa do not enjoy the same educational opportunities as their more privileged counterparts. Transformation of the education system is required to allow previously advantaged and disadvantaged schools to enter into projects such as these on a more equitable footing, as equal partners. 


\section{References}

Bush, T., \& Glover, D. (2014). School leadership and management in South Africa. International Journal of Education Management, 30(2), 211-231.

Christie, P. (2016). Educational change in post-conflict contexts: Reflections on the South African experience 20 years later. Globalisation, Societies and Education, 14(3), 434-446.

Creswell, J. W. (2014). Research design, qualitative, quantitative and mixed methods approaches (4th ed.). Thousand Oaks, USA: SAGE.

de Lange, N., Moletsane, R., \& Mitchell, C. (2015). Seeing how it works: A visual essay about critical and transformative research in education. Perspectives in Education, 33(4), 151-176.

Fleischmann, E. M., \& Van der Westhuizen, C. (2017). The Interactive-GIS-Tutor (IGIST): An option for GIS teaching in resource-poor South African schools. South African Geographical Journal, 99(1), 68-85.

Grayling, A. C. (2010). Thinking of answers. London, UK: Bloomsbury.

Harris, C. J. (2016). The effective integration of technology into schools' curriculum. Distance Learning, 13(2), 27-37

Kalp, F., \& Maritz, H. (2009). Ligbron Academy of Technology project. Retrieved from https://ligbron.co.za/e-learning-project/

Leahy, M., Davis, N., Lewin, C., Charania, A., Nordin, H., Orlič, D., Butler, D. \& Lopez-Fernadez, O. (2016). Smart partnerships to increase equity in education. International Forum of Educational Technology \& Society, 19(3), 84-98.

Letwinsky, K. M. (2017). Examining the relationship between secondary mathematics teachers' selfefficacy, attitudes, and use of technology to support communication and mathematics literacy. International Journal of Research in Education and Science, 3(1), 56-66.

Liu, D., Huang, R., \& Wosinski, M. (2017). Smart learning in smart cities. Singapore: Springer.

Lusenga, R. M. (2010). School leaders' moral understanding and moral reasoning (Unpublished master's thesis). University of Pretoria, South Africa.

Mathole, Y. (2016). Using Content and Language Integrated Learning (CLIL) to address multilingualism in South African schools. European Journal of Language Policy, 8(1), 56-77. https://doi:10.3828/eilp.2016.5

Merriam, S. B. (2002). Qualitative research in practice: Examples for discussion and analysis. San Francisco, USA: Jossey-Bass.

Merriam, S. B. (2009). Qualitative research: A guide to design and implementation. San Francisco, USA: Jossey-Bass.

Mlitwa, N. W., \& Korangteng, K. (2013). Integration of ICT into curricula in Western Cape schools: The activity theory perspectives. The Journal of Community Informatics, 9(4). Retrieved from http://cijournal.org/index.php/ciej/article/view/957

Moloi, K. C., Gravett, S. J., \& Petersen, N. F. (2009). Globalization and its impact on education with specific reference to education in South Africa. Educational Management Administration \& Leadership, 37(2), 278-297.

Republic of South Africa, Department of Basic Education. (2010). Education Statistics in South Africa 2009. Pretoria, South Africa: Department of Basic Education.

Simons, J. (2006). Introduction. In J. Simons (Ed.), Contemporary critical theorists: From Lacan to Said (pp. 1-18). Edinburgh, UK: Edinburgh University Press. 
South African Consortium on Monitoring Education Quality. (2005). Kenya SACMEQ II report. Harare, Zimbabwe: SACMEQ. Retrieved from http://www.sacmeq.org/links.htm

Spaull, N. (2013). South Africa's education crisis: The quality of education in South Africa 1994-2011. Johannesburg, South Africa: Centre for Development and Enterprise.

Strauss, D. F. M. (2009). Philosophy: Discipline of the disciplines. Grand Rapids, USA: Paideia.

Timaeus, I. M., Simelane, S., \& Letsoalo, T. (2013). Poverty, race, and children's progress at school in South Africa. Journal of Development Studies, 49(2), 270-284.

Ungerer, L. M. (2014). Transformative consumer research: Its origins and possible enrichment of the field of consumer research in South Africa. SA Journal of Industrial Psychology/SA Tydskrif vir Bedryfsielkunde, 40(1), Art. \#1163, 15 pages. doi: https://doi.org/10.4102/saiip.v40i1.1163

Van der Berg, S. (2008). How effective are poor schools? Poverty and education outcomes. Studies in Educational Evaluation, 34, 145-154.

Van der Berg, S., Taylor, S., Gustafsson, M., Spaull, N. \& Armstrong, P. (2011). Improving education quality in South Africa: Report for the National Planning Commission. University of Stellenbosch. Retrieved from http://resep.sun.ac.za/wp-content/uploads/2012/10/2011-Report-for-NPC.pdf 